$\xi=$

\title{
Yoga practices for different blood types based on occidental - oriental food habits
}

\author{
Acharya Balkrishna ${ }^{1}$, Paran Gowda ${ }^{2}$, Rachana Bhattarai ${ }^{3 *}$, Rudra B. Bhandari ${ }^{4}$, \\ Kuldeep Singh ${ }^{5}$, Anita Verma ${ }^{6}$ \\ ${ }^{1}$ Founder, Patanjali Institutions, Haridwar, Uttarakhand, India \\ ${ }^{2}$ Professor, Patanjali University Haridwar, Uttarakhand, India \\ 3* Continental Food and Nutrition Expert, Patanjali Food Park, Haridwar, Uttarakhand, India and Chairperson, \\ Rachnaaz educational and charitable trust Chennai \\ ${ }^{4}$ Asst. Professor, Patanjali University, Haridwar, Uttarakhand, India \\ ${ }^{5}$ Head Dental Clinic and Research Centre, Patanjali Ayurved Hospital, Haridwar, Uttarakhand, India \\ ${ }^{6}$ Research Scholar, Patanjali University, Haridwar, Uttarakhand, India \\ *Corresponding author E-mail: rachnaaztrust@gmail.com
}

\begin{abstract}
Objective: The objective of this paper is to bring the relationship between blood types versus Occidental - Oriental Food Habits (OOFH) along with Yoga practices for better public health and wellness.

Methodology: Sample sizes of 50 persons are selected for the study. Clinical blood type classifications and suitable diet combinations, OOFH items are worked out by trial and error method in a laboratory. A Yoga Wellness scoring card or impact card is developed to measure yoga practices.

Results: The trial and error method led to innovative development of 10 basic organic food items with 50,000 variations are shown empirically for clinically tested 4 blood groups. Secondly, by using OOFH items, one can maintain a healthy body-mind. Thirdly, yoga wellness card is developed can be used as a health education and communication tool for healthy life style. Lastly, stress related issues are treated with variant juices.

Conclusions: The study concludes, that a recommended OOFH diet along with Wellness card helps the individuals to maintain a disease free body-mind of clinically classified of blood types. There is a scope for further research work.
\end{abstract}

Keywords: Blood types; Food habits; Health; Lifestyle; Yoga

\section{Introduction}

The medical fraternity and scientists across the globe have not subscribed concretely the blood group relation with food habits. All life styles on earth shares a common ancestral ancestor known as the last universal common ancestor (Doolittle et al. 2000, Kaplan et al. 2008, Kampourakis 2014), which lived approximately 3.5-3.8 billion years ago (Glansdorff et al. 2008), although a study in 2015 found "remains of biotic life" from 4.1 billion years ago in ancient rocks in Western Australia (Borenstein, Bell et al 2015). In July 2016, scientists reported identifying a set of 355 genes from all living beings on Earth (Wade 2016).

In this article, we are proposing a new mix of Occidental-Oriental Food Habits (OOFH) with new recipes and blood groups. We included yoga as a Health education and Communication tool for public health to relax the body-mind coordination for better life style and group wellness. Yoga is a 5,000-year-old physical, mental and spiritual practice having its origin in India, which aims to transform both body and mind. On December 11 in 2014, the United Nations General Assembly declared June $21^{\text {st }}$ as the International Day of Yoga. The Indian Prime Minister in his UN address suggested the day $21^{\text {st }}$ June as it is the longest day of the year in the Northern Hemisphere and shares a special significance in almost all parts of the world.
As per the medical science, the ABO system is one of the most important blood group systems in transfusion/transplantation medicine. However, the evolutionary significance of the $\mathrm{ABO}$ gene and its polymorphism remained unknown (Fumiichiro et al. 2014). As per the unpublished report (Fat sheet 2017, Available at: https://www.fatsecret.com/calories-nutrition/) on "Bloodtronics" (yet to be published paper by one of the authors), modern blood group classification is related to the origin of human kind from the Darwin's theory of evolution. The assumption made in this report is that blood type is related to evolutionary theory of change. As per the theory, group $\mathrm{O}$ is considered to be the ancestral blood group in humans and their basic food is consumption of high animal protein diets - a typical animal food for the community who lived in forests of by gone era called as Stone Age hunters. In contrast, those with group A should thrive on a vegetarian food like jungle wide fruits as this blood group was believed to have evolved when humans settled down into Agrarian societies. Following the same rationale, individuals with blood group B are considered to benefit from consumption of dairy products because this blood group was believed to originate in nomadic tribes. Finally, individuals with an $\mathrm{AB}$ blood group are believed to benefit from a diet that is intermediate to those proposed for groups $\mathrm{A}$ and B. 
Some researchers believe blood types are associated with personality traits related to Psychology. Many medical surveys (Fumiichiro 2014) have been conducted, such as those for hormone secretion traits (DBH, COMT, and MAO etc.) or the bloodtype antigens in neurons, or the antigens expressed on surfaces of brain cells. But these studies are not yet fully confirmed, except that the $\mathrm{ABO}$ antigens are expressed in early embryos.

\section{Method}

During a study period of 8 weeks, a general survey was carried out among the general public including staff members and students at Patanjali Yogpeeth and at University of Patanjali, Haridwar. Out of 100 , the stratified data sample size was 50 . A clinical test is conducted to get the blood types of all participants. The target group is from the staff members from the dental unit of Yogpeeth and also from the University of Patanjali. Simultaneously we prepared OOFH items by trial and error method at our laboratory. A secondary data was collected from various research journals including psychological parametric tests data. Further we supplemented our findings from literature survey of various national and international journals. For example we have quoted from the American Journal of Epidemiology to validate our primary findings.

One of the co-authors Ms. Rachna Bhattarai has done extensive research on blood groups and food habits. She has worked with the food habits of about 100 patients in different hospitals in Chennai whose data had to be kept confidential due to the hospital privacy policies.

\subsection{Inclusion criteria}

1) Subject is a male or female between the age of 16 and 45 .

2) Subject has been a yoga practitioner for at least 1 year.

3) Subject does not have a history of any major illness past 6 months and minor illness past 1 week.

4) Subject consumes Organic Food and Herbal Supplements.

\subsection{Exclusion criteria}

1) Subject suffering from any dietary disorders.

2) Subject who consumes junk food, tobacco, cigarette or alcohol.

3) Subject having irregular sleep cycle.

\subsection{Food recipe chain and its empirical formula}

By trial and error method, a recipe empirical formula is developed along with its variations and tested with the basic ingredients which are given in the Table 1 along with the formula
Table 1: Relation between Blood Types - Food Ingredients

\begin{tabular}{|c|c|c|c|}
\hline $\begin{array}{l}\text { S. } \\
\text { No. }\end{array}$ & $\begin{array}{l}\text { Blood } \\
\text { Type }\end{array}$ & $\begin{array}{l}\text { General Food } \\
\text { Habits based on Evo- } \\
\text { lution theory }\end{array}$ & $\begin{array}{l}\text { Basic } \\
\text { Organic Food ingredients } \\
\text { used in preparation }\end{array}$ \\
\hline 1 & A & Vegetarian diet & $\begin{array}{l}\text { Millets, wheat and vegeta- } \\
\text { bles }\end{array}$ \\
\hline 2 & B & Dairy Products & Milk, Curd, Sweets etc \\
\hline 3 & $\mathrm{O}$ & High protein diet & Millets, Pulses, Soya-Milk \\
\hline 4 & $\mathrm{AB}$ & $\begin{array}{l}\text { Combination of A and } \\
\mathrm{B} \text { groups }\end{array}$ & $\begin{array}{l}\text { Curd Rice, Fruit shake, } \\
\text { Milk shake }\end{array}$ \\
\hline
\end{tabular}

Note: Only organic food is considered in the above table. One can have its equivalent non-vegetarian food.

\subsection{Yoga wellness score card /impact}

Yoga wellness may be defined as a healthy (body + mind) and happy life of an individual. A benefit / impact scorecard (Atkins 2014) is developed to provide a preliminary assessment of effect of yoga on body-mind relation. The wellness is achieved by a balanced diet through OOFH and with breathing techniques. The combined effect of wellness is measured - something on the lines of Likert scale adopted and it addresses the range of wellness of healthy body and mind with future proofing wellness dimensions defined as follows;

$5=$ very high, $4=$ high, $3=$ medium, $2=$ low, $1=$ very low or no impact.

\section{Results}

Based on Table 1 given in methods, the recipe diet energy values are calculated in calories and are given in Table 2. The Table 2 shows the data on daily intake of OOFH converted into energy units and classified according to the blood groups of the individuals

Experiments carried out in our laboratory on food preparations and its variants have let us arrive at a suitable diet form of OOFH of different products as shown in Table 3 .

Table 4 gives the empirical formula relation with different blood groups. Because of the large variants involved in the preparation of OOFH recipes, we took the help of elementary mathematics of summing up these two factors - one factor is basic and the second is its variant denoted by letters $P_{i}$ and $R_{j}$. The subscripts ' $i$ ' and ' $j$ ' denote real integer values varying from 1 to 50,000 . We have to use the sigma symbol because of large variants involved in the basic recipe items. These items are tested with fifty different blood group participants as given in Table 2 .

In our previous sample study of 50 cases (Acharya et al. 2017) it was shown that 4 major blood groups have almost the same food habits in term of calorie intake.

At present also we have considered the same group of 50 persons and carried out the studies with yoga wellness card and with OOFH shown in Table 6

Table 2: Relation between Blood Types - Recipe Diet - Suggested Calories Intake

\begin{tabular}{|c|c|c|c|c|}
\hline S.No. & Blood Type & Recipe diet & $\begin{array}{l}\text { Calories energy intake per } \\
\text { day (Fat sheet 2017) }\end{array}$ & Nutritional diet \\
\hline 1 & A & $\begin{array}{l}\text { Combination of } 3 \text { basic ingredients } \\
\text { - grains, vegetables and milk }\end{array}$ & $\begin{array}{l}240+180+1 \text { cup, } 167= \\
587\end{array}$ & $\begin{array}{l}\text { The nutritional grains diet contains carbo- } \\
\text { hydrates } 42 \text { gms, } 4 \text { grams of fat and } 10 \\
\text { gms of protein in grains } \\
\text { Nutritional vegetable diet in } 1 \text { package } \\
\text { contains little quantities of fats, proteins } \\
\text { and carbohydrates } \\
\text { Milk contains a small percentage of fats, } \\
\text { proteins and carbohydrates } \\
\text { All } 3 \text { basic ingredients with its derivatives } \\
\text { matches the standard calories and also with } \\
\text { the nutritional standards }\end{array}$ \\
\hline 2 & $\mathrm{~B}$ & $\begin{array}{l}\text { Combination of two basic ingredi- } \\
\text { ents-Milk and jaggary }\end{array}$ & $\begin{array}{l}167 \text { ( } 1 \text { cup })+383(100 \mathrm{gms}) \\
=550\end{array}$ & Jaggary has also $100 \%$ carbohydrates \\
\hline 3 & $\mathrm{O}$ & Combination of Grains and Milk & $240+1$ cup, $167=307$ & Supplemented with its chain calories \\
\hline 4 & $\mathrm{AB}$ & Grains, Vegetables and milk & $240+180+167=587$ & It is same as A type blood nutrition \\
\hline
\end{tabular}

Note: Only organic food is considered in the above table. One can have its equivalent non-vegetarian food. 
Table 3: Typical OOFH Recipes with Variations Tested and Developed At Our R\&D Centre

\begin{tabular}{|c|c|c|}
\hline S.No. & Recipe & No. of variations \\
\hline 1 & Mango & 2000 \\
\hline 2 & Jam & 78 \\
\hline 3 & Snacks & 468 \\
\hline 4 & Vegetables & 869 \\
\hline 5 & Soups & 319 \\
\hline 6 & Pulses with curd & 160 \\
\hline 7 & Pickles & 72 \\
\hline 8 & Butter milk with chips & 62 \\
\hline 10 & Noodles & 45 \\
\hline 11 & Wheat pasta & 78 \\
\hline 12 & Confectionaries & 671 \\
\hline 13 & European / Indian bread items & 239 \\
\hline 14 & Cream items & 50 \\
\hline 15 & Pizza/Burger & 327 \\
\hline
\end{tabular}

Table 4: Relation between Blood Types - OOFH Recipe and Its Variation Formula

\begin{tabular}{|c|c|c|c|}
\hline S.No. & Blood Type & Recipe and its variation formula - OOFH & Explanation \\
\hline 1 & A & $\sum_{i=1}^{2} P_{\mathrm{i}}+\sum_{j=1}^{\operatorname{lng}} R_{\mathrm{j}}$ & $\begin{array}{l}P_{i} \text { with } 3 \text { basic ingredients - Millets, Green vegetable, Milk and } \\
R_{j} \text { with } 15,000 \text { diversified products. }\end{array}$ \\
\hline 2 & B & $\sum_{\mathrm{i}=\mathrm{i}}^{\mathrm{d}} P_{\mathrm{I}}+\sum_{\mathrm{j}=1}^{10000} R_{\mathrm{j}}$ & $\begin{array}{l}P_{i} \text { with } 2 \text { basic ingredients - Milk, Jaggary and } R_{j} \text { with 10,000 } \\
\text { variations. }\end{array}$ \\
\hline 3 & $\mathrm{O}$ & $\sum_{i=1}^{2} P_{1}+\sum=1$ & $\begin{array}{l}P_{i} \text { is a summation of } 2 \text { basic ingredients }- \text { Grain and Milk and } R_{j} \\
\text { is a recipe variation chain with } 5,000 \text { diversified products. }\end{array}$ \\
\hline 4 & $\mathrm{AB}$ & $\sum_{\mathrm{i}=\mathrm{i}} P_{\mathrm{i}}+\sum_{\mathrm{j}=1}^{20000} R_{\mathrm{j}}$ & $\begin{array}{l}P_{i} \text { is a summation of } 3 \text { basic ingredients - Whole grain, Vegeta- } \\
\text { bles and Milk and } R_{j} \text { is a recipe variation chain with } 20,000 \text { di- } \\
\text { versified products. }\end{array}$ \\
\hline
\end{tabular}

Note: Only organic food is considered in the above table. One can have its equivalent non-vegetarian food.

OOFH examples are given in Table 5 in the form of empirical relations.

Table 5: A Typical Mix of Occidental and Oriental Foods

\begin{tabular}{|c|c|c|c|}
\hline S.No. & Oriental & Occidental & Ori+Occi Recipes \\
\hline 1 & Pickle & Salad & $=\sum_{i=-1} P j+\sum_{i=1} R \tilde{i}$ \\
\hline 2 & Jam and jelly & Candy & $\mathrm{M}=\sum_{i=1} P_{j}+\sum_{j=1} R i$ \\
\hline 3 & Soup based on herbs & Soup based on sauce & Soup based on both herb and sauce (one can write empirically) \\
\hline 4 & $\begin{array}{l}\text { Millets, corn soup and } \\
\text { sweets }\end{array}$ & Oats and broken wheat & $\begin{array}{l}\text { Mixture of all, but highly concentrate on small millet as it contain zero } \\
\text { glutton (one can write empirically) }\end{array}$ \\
\hline 5 & $\begin{array}{l}\text { Pulses and vegetable recipe } \\
\text { (toss, boil, fry) }\end{array}$ & $\begin{array}{l}\text { Boil, baked, } \\
\text { grilled and roasted }\end{array}$ & Our recipe consist of both roast, grill, boil (one can write empirically) \\
\hline
\end{tabular}

Note: Only organic food is considered in the above table. One can have its equivalent non-vegetarian food.

Table 6: Data of 50 Participants with Blood Group, OOFH and Yoga Wellness Card

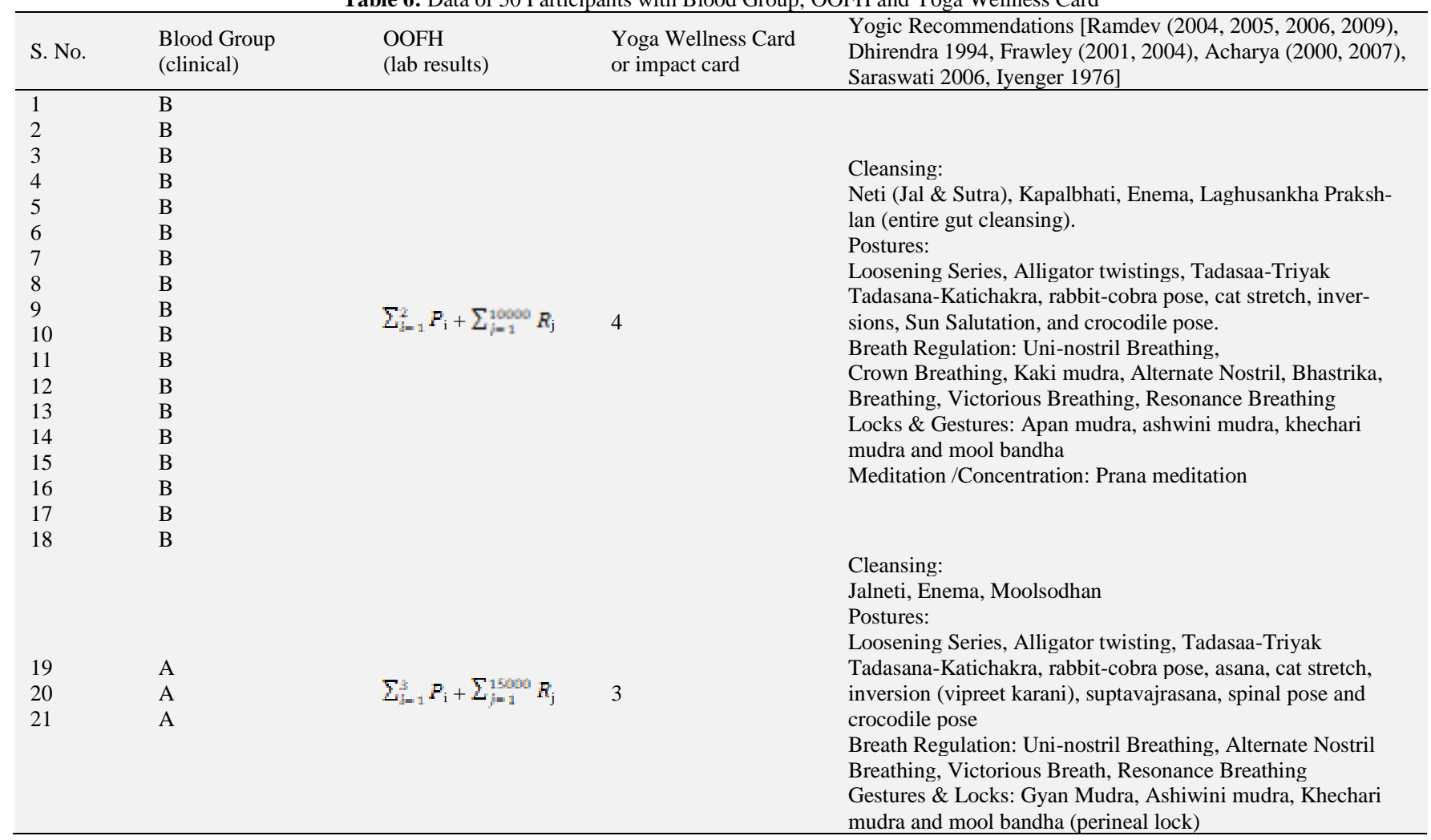






The Fig. 1 shows the percentage classification of blood types in Pie chart form.

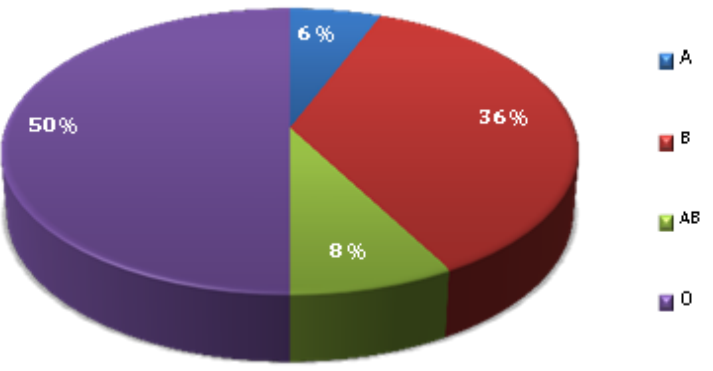

Fig. 1: Blood Types Percentage.

\section{Discussion}

It can be observed that $50 \%$ of the participants possess blood group $\mathrm{O}$, making it the most commonly found thirty five blood group systems are recognized by the International Society of Blood transfusion- 2 dominant systems are $\mathrm{ABO}$ and Rh (D'adamo 1997) . According to these two systems, the four major blood groups are $\mathrm{A}, \mathrm{B}, \mathrm{AB}$ and $\mathrm{O}$. The presence or absence of $\mathrm{Rh}$ factor determines the $+v e$ or - ve sign before a blood group. Blood volume is mainly composed of 55\% plasma and $45 \%$ blood cells. Blood groups naming are done on the basis of presence or absence of antigens on the surface of red blood cells. The presence and lack of blood antigens in some blood groups induce blood membrane changes, morphologically and functionally. The structuredependent functions of blood types can link the blood groups to health and diseases (Lögdberg et al. 2005).

A recent study found people with type $\mathrm{AB}$ blood were 82 percent more likely to experience difficulties with memory recall, language, and attention than people with other types (Sandler et al. 1994). One reason, researchers suspect, is due to the key clotting protein, known as coagulation factor VIII, which may actually reduce the quality of blood flow to the brain, rather than sealing up injury sites.

Table 7: Mental Stress and Suggested OFCC

\begin{tabular}{|c|c|c|}
\hline $\begin{array}{l}\text { Blood } \\
\text { Type }\end{array}$ & General Disorder & Suggested OFCC (Table 5) \\
\hline A & $\begin{array}{l}\text { Memory problems, cardiac } \\
\text { diseases }\end{array}$ & $\begin{array}{l}\text { Herbal juice, unpolished } \\
\text { pulses }\end{array}$ \\
\hline B & $\begin{array}{l}\text { Stress and anxiety problems, } \\
\text { gastric problems }\end{array}$ & Variant herbal juices \\
\hline $\mathrm{O}$ & Higher risk of inflammation & $\begin{array}{l}\text { Aloe vera juice, Cow urine } \\
\text { ark, Mustard oil }\end{array}$ \\
\hline $\mathrm{AB}$ & $\begin{array}{l}\text { Lower oestrogen level in } \\
\text { females }\end{array}$ & Variant Juices \\
\hline
\end{tabular}

Multiple studies have found a correlation between a woman's blood type and the reproductive system. One study by researchers at Yale University and New York's Albert Einstein College of Medicine found that women with blood type $\mathrm{O}$ are twice as likely to have a lower egg count and poorer egg quality as others (Wadley et al. 2014). The researchers measured the level of repro- 
ductive hormone FSH in the women and adjusted for other fertility factors, such as age and BMI. Women with blood type $\mathrm{O}$ were more likely to have higher levels of $\mathrm{FSH}$, indicating a low ovarian reserve. A 2012 study from Harvard University found people with non-O blood also happen to have an increased risk for cardiovascular disease (Locke 2010). But those with type AB blood were the most at-risk overall, demonstrating a 23 percent greater chance of suffering from heart disease than type $\mathrm{O}$ subjects. Further, certain blood types are more likely to co-occur with varying levels of hormones in the body, physicians commonly tailor their exercise recommendations to the patient's type. People with type-A blood, for example, are more likely to have higher levels of cortisol, the stress hormone, in their body. When the adrenal gland dumps more and more cortisol into the blood, people's stress response grows more acute (He et al. 2012).

\section{Conclusion}

Occidental-Oriental Food Habits (OOFH) with 10 basic food items and its 50000 variants are expressed empirically and accordingly suggested to different 4 blood types. Yoga Wellness Score card is suggested to measure the impact of yoga (50 nos.) on body-mind combined.

\section{Acknowledgement}

We could complete this paper with the blessings of His Holiness Swami Ramdev Ji, founder of Patanjali institutions and Chancellor of Patanjali University. Our sincere thanks to the Patanjali Dental department staff members Dr. Kuldeep and others. We would also like to thank the students of University of Patanjali for providing information about their blood groups.

\section{References}

[1] Acharya SS (2000), Super science of Gayatri, Haridwar, India, Yugantar Chetna Press, available from http://literature.awgp.org/var/node/1463/super_science_gayatri.pdf.

[2] Acharya SS (2007), Brahmabarchas, Pragya yoga for healthy and happy life, Haridwar, India, Shri Vedmata Gayatri Trust, Available at

http://literature.awgp.org/var/node/1583/Pragya_yog_for_happy_an d_healthy_life.pdf

[3] Acharya Balkrishna, Anita Verma, Rachna Bhattarai, G.P. Gowda (2017), Effect of Yoga on general health: food habits versus blood groups, International Journal of Community Medicine and Public Health, pp.1923-1927.

[4] Atkins (2014), Future proofing of Indian cities, Madurai, India.

[5] Bell Elizabeth A, Boehnike Patrick, Harrison T. Mark (2015), Potentially biogenic carbon preserved in a 4.1 billion-year-old zircon, Proc. Natl. Acad. Sci. U.S.A. Washington D.C, National Academy of Sciences. 112 (47), 14518-14521.

[6] Borenstein Seth (2015), Hints of life on what was thought to be desolate early Earth, Excite. Yonkers, NY, Mindspark Interactive Network. Associated Press.

[7] D'adamo PJ, (1997), Eat right for your type, New York, Putnam Adult.

[8] DhirendraBrahmachari, (1994), Accessed at http://www.worldyogadirectory.com/Yoga-Teachers/SwamiDhirendra-Brahmachari-1227.html

[9] Doolittle W. Ford (2000), Uprooting the Tree of Life, Scientific American. Stuttgart: Georg von Holtzbrinck Publishing Group, 282 (2), 90-95.

[10] Fat sheet (2017), Accessed online from "https://www.fatsecret.com/calories-nutrition/.

[11] Frawley D, Summerfield S (2001), Yoga for your type: An Ayurvedic approach for your asana practice, Twin Latkes, WI: Lotus Press.

[12] Frawley D Summerfield (2014), S Yoga and the Sacred Fire, Selfrealization and Planetary Transformation, Lotus Press, p. 8, ISBN 0-940985-75-6.

[13] Fumiichiro Yamamoto, Emili Cid, Miyako Yamamoto, Naruya Saitou, Jaume Bertranpetit \& Antoine Blancher (2014), An integrative evolution theory of histo-blood group $\mathrm{ABO}$ and related genes, Scientific Reports 4, doi:10.1038/srep06601, Evolutionary biology Glycobiology Immuno genetics. https://doi.org/10.1038/srep06601.

[14] Glansdorff Nicolas, Ying Xu, Labedan, Bernard (2008), The Last Universal Common Ancestor: emergence, constitution and genetic legacy of an elusive forerunner, Biology Direct, London, BioMed Central, 3(29)

[15] He M, Wolpin B, Rexrode K, Manson JE, Rimm E, Hu FB, et al (2012), ABO blood group and risk of coronary heart disease in two prospective cohort studies, Arteriosclerosis, thrombosis, and vascu$\begin{array}{lll}\text { lar } & \text { 32(9), } & \text { 2314-20 }\end{array}$ https://doi.org/10.1161/ATVBAHA.112.248757.

[16] Iyengar B. K. S. (1976), Light on Yoga (2nd ed.), New York, Schocken Books.

[17] Kampourakis (2014), Understanding Evolution, Cambridge, New York, Cambridge University Press, ISBN 978-1-107-03491-4, $127-$ 129

[18] Kaplan GA, Shema SJ, Leite CM (2008), Socio-economic determinants of psychological well-being - the role of income, income change, and income sources during the course of 29 years. Ann Epidemiol, 18 (7), 531-537. https://doi.org/10.1016/j.annepidem.2008.03.006.

[19] Locke T (2010), A study on Blood Type O Linked to Fertility Problems, Available at: http://www.webmd.com/infertility-and reproduction /news/20101025/blood-type-o-linked-fertility- problems.

[20] Lögdberg L, Reid ME, Lamont RE, Zelinski T (2005), Human blood group genes, chromosomal locations and cloning strategies, Transfusion medicine reviews, 19(1), 45-57. https://doi.org/10.1016/j.tmrv.2004.09.007.

[21] Ramdev Swami (2004), Vitality Strengthening Astavarga Plants (Jeevaniya \& Vayasthapan Paudhe), Divya Yog Mandir Trust, ISBN 978-81-89235-03-1.

[22] Ramdev Swami (2005), Aushadh Darshan, Diamond Pocket Books (P) Ltd, ISBN 978-81-89235-24-6.

[23] Ramdev Swami (2006), Yog Its Philosophy \& Practice, Diamond Pocket Books Ltd, ISBN 978-81-89235-15-4.

[24] Ramdev Swami (2009), Prāṇāyāma Rahasya, Secrets of Prāṇāyāma, with Scientific Factual Evidence, Diamond Pocket Books Ltd, ISBN 978-81-89235-01-7.

[25] Sandler SG, Mallory D (1994), Biological functions of blood groups in health and disease, Haematologia, 27(1), 1-3.

[26] Saraswati SS (2006), A Systematic course in the ancient tantric techniques of yoga and kriya, Munger, India, Yoga Publication Trust.

[27] Wade Nicholas (2016), Meet Luca, the Ancestor of All Living Things, New York Times, Retrieved July 25, 2016.

[28] Wadley V, Unverzagt F, Cushman M (2014), ABO blood type, factor VIII, and incident cognitive impairment in the Cohort. Neurol. 83(14), 1271-6. https://doi.org/10.1212/WNL.0000000000000844. 